Bull. Mater. Sci., Vol. 23, No. 4, August 2000, pp. 243-248. (C) Indian Academy of Sciences.

\title{
Ceramic joining through reactive wetting of alumina with calcium aluminate refractory cements
}

\author{
K GEETHA, A M UMARJI* and T R N KUTTY \\ Materials Research Centre, Indian Institute of Science, Bangalore 560 012, India
}

MS received 31 March 2000; revised 5 June 2000

\begin{abstract}
Compositions in $\mathrm{CaO}-\mathrm{Al}_{2} \mathrm{O}_{3}$ system have been prepared by gel-to-crystallite conversion method. Reactive powders of $1: 2,1: 1,2: 1$ and $3: 1$ of $\mathrm{CaO}$ and $\mathrm{Al}_{2} \mathrm{O}_{3}$ compositions were obtained by calcining the product at $800-1200^{\circ} \mathrm{C}$. Fine grained powders were used as refractory cement for joining alumina ceramics. An optimum temperature of $1450^{\circ} \mathrm{C}$ for $4 \mathrm{~h}$ produced joints of satisfactory strength. The microstructure and $\mathrm{X}$-ray phase analysis of the fractured joint surface clearly indicate reactive wetting of the alumina ceramics. This wetting enhances the joining of alumina substrates and can be attributed to the formation of $\mathrm{Ca}_{12} \mathrm{Al}_{14} \mathrm{O}_{33}$ liquid phase. The results are explained by using $\mathrm{CaO}-\mathrm{Al}_{2} \mathrm{O}_{3}$ phase diagram.
\end{abstract}

Keywords. $\mathbf{G} \rightarrow \mathrm{C}$ conversion; reaction bonding; alumina ceramics; calcium aluminate; high temperature cements.

\section{Introduction}

Many complex ceramic joining techniques have been developed for ceramic-to-metal and ceramic-to-ceramic joining. The electronic, mechanical, crystallographic and thermodynamic changes occuring in the interfaces of the joints have resulted in development of unique joining techniques like diffusion bonding (Bates et al 1990), brazing (Loeman and Tomsia 1988), glass frit joining (Walls and Ueki 1992), fusion and friction welding (Fernie 1997) and microwave joining (Meek and Blake 1986; Palaith and Silberglitt 1989). Most of the ceramic joining investigations are carried out in non-oxide ceramics such as $\mathrm{AlN}, \mathrm{Si}_{3} \mathrm{~N}_{4}, \mathrm{SiC}$ etc while $\mathrm{ZrO}_{2}$ and $\mathrm{Al}_{2} \mathrm{O}_{3}$ are the usually considered oxide materials for many applications. The literature about alumina joining is very much limited when compared to other ceramics like $\mathrm{Si}_{3} \mathrm{~N}_{4}$ and $\mathrm{SiC}$.

Alumina, both as single crystal and in polycrystalline form, has remarkable properties in comparison to the conventional porcelains and other oxide ceramics. Application of alumina ceramics can be greatly enhanced and fabrication costs reduced if simple and reliable joining techniques are developed. One possibility of doing this is to use refractory cements for joining. Binary compounds of $\mathrm{CaO}-\mathrm{Al}_{2} \mathrm{O}_{3}$ system have long been known as refractories especially in furnace lining applications (Parker and Sharp 1982).

Wet chemical methods of preparation is a preferred route for obtaining homogeneous and reactive powders, producing relatively small particle size compared to that

*Author for correspondence prepared using the solid state reaction. The gel to crystallite $(\mathrm{G} \rightarrow \mathrm{C})$ conversion route can yield highly reactive powders as the desired phase can be formed at relatively low temperatures. Reactive powders of various aluminates have been prepared by earlier workers using this method (Kutty and Padmini 1992, 1995; Padmini and Kutty 1994; Kutty et al 1996; Nayak and Kutty 1996; Jayaraman et al 1998). In the present investigation, $G \rightarrow C$ conversion method has been used to prepare reactive refractory cement compositions in $\mathrm{CaO}-\mathrm{Al}_{2} \mathrm{O}_{3}$ system. Joining of alumina ceramics using these cements has been optimized. The joint region has been investigated by XRD, SEM and mechanical pull test.

\section{Experimental}

$\mathrm{G} \rightarrow \mathrm{C}$ conversion method involves the reaction of a hydrated gel such as hydrated alumina gel $\left(\mathrm{Al}_{2} \mathrm{O}_{3} \cdot x \mathrm{H}_{2} \mathrm{O}\right)$ with $\mathrm{M}^{n+}(\mathrm{OH})_{n}$, (where $\mathrm{M}=\mathrm{Ba}^{2+}, \mathrm{Ca}^{2+}, \mathrm{Mg}^{2+}$ etc) in presence of a hydrophilic solvent, such as ethanol, at $80-100^{\circ} \mathrm{C}$ for 4-6 h. Often, the as-prepared form is a crystalline metastable hydroxylate which acts as a precursor. The precursor decomposes on calcination giving rise to the desired end product. Different stoichiometric calcium aluminates were prepared using this method by precipitating the gel using either $\mathrm{AlCl}_{3}$ (Qualigens-LR) or $\mathrm{Al}\left(\mathrm{NO}_{3}\right)_{3} \cdot 4 \mathrm{H}_{2} \mathrm{O}$ (Qualigens-GR grade). The aqueous aluminum nitrate solution was analysed by gravimetry for $\mathrm{Al}_{2} \mathrm{O}_{3}$ content. Stoichiometric amount of calcium ion was added in the form of either $\mathrm{Ca}(\mathrm{OH})_{2}$ or $\mathrm{CaO}$ freshly prepared by decomposing $\mathrm{CaCO}_{3}$ at $\approx 900^{\circ} \mathrm{C}$.

TG/DTA was used to find out the reaction sequence of the calcium aluminates from the precursor to final 
compound and to find the temperature at which the precursor becomes volatile-free. The TG/DTA curves were recorded in air at a heating rate of $15^{\circ} \mathrm{C} / \mathrm{min}$ using an automated simultaneous thermal analyser STA/1500 of Polymer Laboratories. The characterization of the compounds was done using a Scintag/USA X-ray Diffractometer employing $\mathrm{Cu}-\mathrm{K}_{\alpha}$ radiation and $\mathrm{Ni}$ filter. Scanning electron micrographs (SEM) were obtained using a S360 Cambridge scanning electron microscope on fractured surfaces sputtered with a thin layer of gold.

A commercial alundum cement procured from Fisher Scientific, USA was used for comparison of the alumina joining property of prepared cements. The alumina ceramic specimens for reaction studies were prepared in the cylindrical form (10 $\mathrm{mm}$ dia and $15 \mathrm{~mm}$ length) by compacting and sintering submicrometer sized reactive alumina powder. Alumina powder (Alcoa, A-16 grade) is seen to have spherical shape and the average size as calculated from the SEM is about $0.4 \mu \mathrm{m}$. Most of the joining studies were conducted on the alumina substrates sintered at $1450^{\circ} \mathrm{C}$ for $4 \mathrm{~h}$ and having the density of $\geq 90.5 \%$.

The joining possibilities were investigated by varying the joining temperature from 1200 to $1550^{\circ} \mathrm{C}$. Calcium aluminates of the composition $\mathrm{CaAl}_{4} \mathrm{O}_{7}\left(\mathrm{CA}_{2}\right), \mathrm{CaAl}_{2} \mathrm{O}_{4}$ (CA), $\mathrm{Ca}_{12} \mathrm{Al}_{14} \mathrm{O}_{33} \quad\left(\mathrm{C}_{12} \mathrm{~A}_{7}\right)$ and $\mathrm{Ca}_{3} \mathrm{AlO}_{6} \quad\left(\mathrm{C}_{3} \mathrm{~A}\right)$, heat treated at $800-1200^{\circ} \mathrm{C}$ for $4 \mathrm{~h}$, were made in the form of paste using distilled water and then applied to the alumina test specimen surfaces. The pairs of alumina specimens to be joined were kept in the vertical position with the joining surfaces in contact and allowed to dry up in the open atmosphere for $6-10 \mathrm{~h}$ before subjecting them to heat treatment. A home-built pull test apparatus was extensively used for evaluating the comparative strength.

\section{Results}

Most of the as prepared precursor powders were either Xray amorphous or showed broad peaks. TG/DTA data showed a typical residue of 60-70\% after all the volatiles were lost up to $700^{\circ} \mathrm{C}$. TG/DTA run in figure 1 shows the decomposition of the precursor of $\mathrm{C}_{3} \mathrm{~A}$ powder prepared using $\mathrm{G} \rightarrow \mathrm{C}$ conversion method. The initial weight loss at $<200^{\circ} \mathrm{C}$ varies depending upon the drying condition. The weight loss at $315^{\circ} \mathrm{C}$ can be attributed to the decomposition of aluminium hydroxide. The decomposition of calcium hydroxide begins at $450^{\circ} \mathrm{C}$ and goes to completion only at $750^{\circ} \mathrm{C}$. These compositions were calcined between 800 and $1200^{\circ} \mathrm{C}$ for the purpose of getting crystalline refractory cements. Table 1 gives the nominal starting composition, phase identifications as well as the structural and thermal data of the heat-treated compounds. XRD analysis of the calcined powders indicated complete crystalline phases. These phases remain stable on heating up to $1500^{\circ} \mathrm{C}$ except $\mathrm{C}_{2} \mathrm{~A}$, which melts at $1415^{\circ} \mathrm{C}$.
The strength of the joints was evaluated by the pull test and the results tabulated (table 2). As seen from table 2, at $1200^{\circ} \mathrm{C}$ no joining is observed in any of the calcium aluminates and at temperatures $>1400^{\circ} \mathrm{C}, \mathrm{C}_{3} \mathrm{~A}$ joined alumina specimens display comparable strength with that of joints made with commercial alundum cement. The other two compositions viz. $\mathrm{CA}_{2}$ and $\mathrm{CA}$ do not show any joining even at $1500^{\circ} \mathrm{C} . \mathrm{C}_{12} \mathrm{~A}_{7}$ composition, however, showed some joining above $1500^{\circ} \mathrm{C}$. The fractured surface was extensively studied for composition analysis. In all cases, multiphasic XRD spectra were obtained indicating chemical reaction taking place at the joint region. Solid state reaction occurs between $\mathrm{C}_{3} \mathrm{~A}$ and $\mathrm{Al}_{2} \mathrm{O}_{3}$ to form $\mathrm{C}_{12} \mathrm{~A}_{7}$, which is a liquid phase at the reaction temperature and reacts with the $\mathrm{Al}_{2} \mathrm{O}_{3}$ substrates to form $\mathrm{CA}$. The CA formation could be due to the mechanism of interstitial migration of $\mathrm{Al}^{3+}$ ions. In general, the reaction product was richer in alumina contents than the starting $\mathrm{Ca}: \mathrm{Al}$ ratio. Though the relative amounts of the crystalline phases varied, presumably due to the exact location of cleavage surface with respect to the substrate, a common phase formed in all cases was $\mathrm{C}_{12} \mathrm{~A}_{7}$. A typical XRD analysis of the fractured region of $\mathrm{CA}$ joined alumina ceramics by heat treating at $1450^{\circ} \mathrm{C}$ for $4 \mathrm{~h}$ is shown in figure 2 wherein, the interface shows the presence of crystalline phases of $\mathrm{C}_{12} \mathrm{~A}_{7}$ and $\mathrm{CA}$. Figure $2 \mathrm{~b}$ shows the presence of $\mathrm{CA}_{2}, \mathrm{CA}$ and $\mathrm{C}_{12} \mathrm{~A}_{7}$ along with $\alpha$-alumina of the substrate. Histograms of the joint strengths obtained with $\mathrm{C}_{3} \mathrm{~A}$ at different temperatures are shown in figure 3. Temperatures $>1450^{\circ} \mathrm{C}$ were not helpful in preparing stronger joints.

Figure 4 is an SEM picture of the joint with $\mathrm{C}_{3} \mathrm{~A}$ cement showing the bottom substrate, joint region and top substrate. The thickness of the joint region is about $10-$ $30 \mu \mathrm{m}$ and the evidence for the melting nature of the cement is also seen. There is no difference in the interfaces of the joint in between top and bottom substrates. In figure 5 the three cements $\mathrm{CA}, \mathrm{C}_{12} \mathrm{~A}_{7}$ and $\mathrm{C}_{3} \mathrm{~A}$ are compared by presenting SEM pictures of the respective fractured surfaces. Melting of the cement occurs in all the three cases but is more pronounced in the case of $\mathrm{C}_{12} \mathrm{~A}_{7}$.

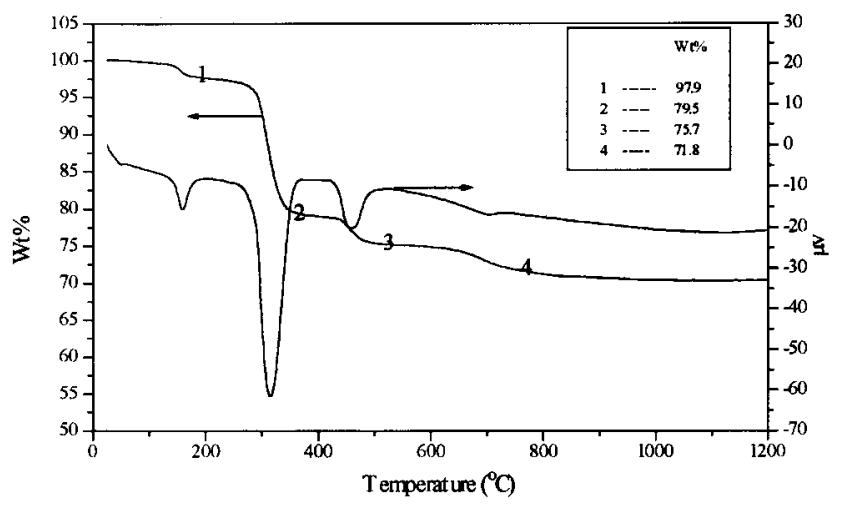

Figure 1. TG/DTA curves of $\mathrm{C}_{3} \mathrm{~A}$ prepared by $\mathrm{G} \rightarrow \mathrm{C}$ conversion route. 
Table 1. Refractory cement compositions and the crystalline phases obtained upon high temperature heat treatment.

\begin{tabular}{|c|c|c|c|c|c|}
\hline $\begin{array}{l}\text { Nominal } \\
\text { composition }^{\dagger}\end{array}$ & $\begin{array}{l}\text { Crystalline phases } \\
\text { identified* }\end{array}$ & $\begin{array}{l}\text { Unit cell } \\
\text { structure }\end{array}$ & $\begin{array}{l}\text { Unit cell } \\
\text { parameters } \\
(\AA)\end{array}$ & $\begin{array}{l}\text { Density } \\
\left(\mathrm{g} / \mathrm{cm}^{3}\right)\end{array}$ & $\begin{array}{l}\text { Melting } \\
\text { point } \\
\left({ }^{\circ} \mathrm{C}\right)\end{array}$ \\
\hline $\begin{array}{l}\mathrm{CaAl}_{4} \mathrm{O}_{7} \\
\left(\mathrm{CA}_{2}\right)\end{array}$ & $\mathrm{CaAl}_{4} \mathrm{O}_{7}$ & Monoclinic & $\begin{array}{l}a=12 \cdot 94 \\
b=8 \cdot 91 \\
c=5 \cdot 45 \\
\beta=107^{\circ}\end{array}$ & $2 \cdot 86$ & 1762 \\
\hline $\begin{array}{l}\mathrm{CaAl}_{2} \mathrm{O}_{4} \\
(\mathrm{CA})\end{array}$ & $\begin{array}{r}\mathrm{CaAl}_{2} \mathrm{O}_{4}+\underset{\text { (minor }}{\mathrm{Ca}_{12} \mathrm{Al}_{14} \mathrm{O}_{33}} \\
\text { quantities) }\end{array}$ & Orthorhombic & $\begin{array}{l}a=8 \cdot 74 \\
b=8 \cdot 10 \\
c=15 \cdot 13\end{array}$ & $2 \cdot 98$ & 1605 \\
\hline $\begin{array}{l}\mathrm{Ca}_{2} \mathrm{Al}_{2} \mathrm{O}_{5} \\
\left(\mathrm{C}_{2} \mathrm{~A}\right)\end{array}$ & $\begin{aligned} & \mathrm{Ca}_{12} \mathrm{Al}_{14} \mathrm{O}_{33}+ \mathrm{C}_{3} \mathrm{~A} \\
& \text { (minor } \\
& \text { quantities) }\end{aligned}$ & Cubic & $a=11.98$ & $2 \cdot 68$ & 1415 \\
\hline $\begin{array}{l}\mathrm{Ca}_{3} \mathrm{Al}_{2} \mathrm{O}_{6} \\
\left(\mathrm{C}_{3} \mathrm{~A}\right)\end{array}$ & $\mathrm{Ca}_{3} \mathrm{Al}_{2} \mathrm{O}_{6}$ & Cubic & $a=7.62$ & $3 \cdot 03$ & 1540 \\
\hline
\end{tabular}

*Crystalline phases identified after heat treatment at $1200^{\circ} \mathrm{C}$ in open air.

${ }^{\dagger}$ Cement chemistry notation: $\mathrm{C}=\mathrm{CaO}$ and $\mathrm{A}=\mathrm{Al}_{2} \mathrm{O}_{3}$.

Table 2. Joint strength as obtained by pulling strength measurement $\left(\mathrm{kg} / \mathrm{cm}^{2}\right)$.

\begin{tabular}{llllll}
\hline & \multicolumn{5}{c}{ Temperature $\left({ }^{\circ} \mathrm{C}\right)$} \\
\cline { 2 - 5 } Cement used & 1200 & 1400 & 1450 & 1500 & 1550 \\
\hline $\mathrm{CA}_{2}$ & not joined & not joined & not joined & not joined & not joined \\
$\mathrm{CA}$ & not joined & not joined & not joined & very weak joint & not joined \\
$\mathrm{C}_{2} \mathrm{~A}$ & not joined & very weak joint & very weak joint & $20-40$ & $10-15$ \\
$\mathrm{C}_{3} \mathrm{~A}$ & not joined & $20-60$ & $30-60$ & $30-60$ & $20-60$ \\
Alundum & very weak joint & $50-70$ & $20-35$ & $40-55$ & weak joint \\
\multicolumn{1}{c}{ cement } & & & & & \\
\hline
\end{tabular}

The molten microstructure indicates the reaction between cement and alumina substrate. Figure $5 \mathrm{~b}$ shows the solidification fronts on cooling in the samples joined using $\mathrm{C}_{12} \mathrm{~A}_{7}$. At the temperature of joining $\left(1450^{\circ} \mathrm{C}\right)$ only $\mathrm{C}_{12} \mathrm{~A}_{7}$ phase is expected to melt. All the other phases $\mathrm{CA}_{2}, \mathrm{CA}$ and $\mathrm{C}_{3} \mathrm{~A}$ have much higher melting points. To confirm the above observation, pellets made out of these three cements were heated separately on a platinum foil to $1450^{\circ} \mathrm{C}$. While $\mathrm{C}_{12} \mathrm{~A}_{7}$ melted, there was no evidence of melting or decomposition of the $\mathrm{CA}$ and $\mathrm{C}_{3} \mathrm{~A}$ phases. This is in agreement with the published $\mathrm{CaO}-\mathrm{Al}_{2} \mathrm{O}_{3}$ phase diagram (Taylor 1990), a portion of which is given in figure 6 . This reveals that $\mathrm{C}_{12} \mathrm{~A}_{7}$ has the lowest melting point at $1415^{\circ} \mathrm{C}$ while $\mathrm{C}_{3} \mathrm{~A}$ melts at $1540^{\circ} \mathrm{C}$ and $\mathrm{CA}$ at $1605^{\circ} \mathrm{C}$. Two eutectic points at $1400^{\circ} \mathrm{C}$ and $1390^{\circ} \mathrm{C}$ for $\left(\mathrm{C}_{3} \mathrm{~A}\right.$ and $\left.\mathrm{C}_{12} \mathrm{~A}_{7}\right)$ and $\left(\mathrm{C}_{12} \mathrm{~A}_{7}\right.$ and $\left.\mathrm{CA}\right)$, respectively covering a wide range of compositions from $\mathrm{C}_{3} \mathrm{~A}$ to $\mathrm{CA}$ are indicated in the phase diagram. This could explain the small amount of joining observed in some cases at $1400^{\circ} \mathrm{C}$.

The extent of reaction happening at different temperatures can be analysed from the XRD patterns of the alumina joints prepared using $\mathrm{C}_{3} \mathrm{~A}$ at temperatures of $1400-1550^{\circ} \mathrm{C}$ as given in figure 7 . At $1400^{\circ} \mathrm{C}$, mainly the

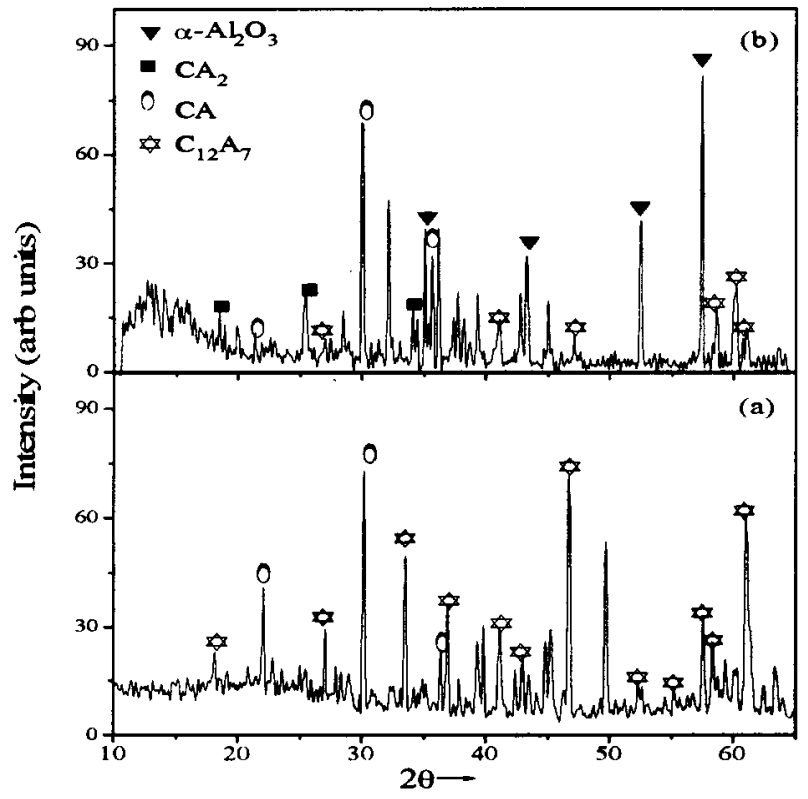

Figure 2. XRD patterns of the fractured region of alumina joints prepared using calcium aluminate of the composition CA by heating at $1450^{\circ} \mathrm{C}$ for $4 \mathrm{~h}$ (a) middle region and (b) surface of the joint. 
$\mathrm{C}_{3} \mathrm{~A}$ and $\mathrm{C}_{12} \mathrm{~A}_{7}$ phases are seen while $\mathrm{CA}$ is present only in small amounts. At $1450^{\circ} \mathrm{C}$, the $\mathrm{CA}$ and $\mathrm{C}_{12} \mathrm{~A}_{7}$ are of almost equal amounts, along with some $\mathrm{C}_{3} \mathrm{~A}$. At $1500^{\circ} \mathrm{C}$ onwards, the CA phase dominates in comparison to $\mathrm{C}_{12} \mathrm{~A}_{7}$.

\section{Discussion}

From the above results it can be clearly concluded that calcium aluminates applied as cement on the alumina surfaces react with the substrates to form alumina-rich compounds at high temperatures. Out of the phases considered, calcia rich $\mathrm{C}_{3} \mathrm{~A}$ takes up more $\mathrm{Al}^{3+}$ from the substrate. Diffusion of $\mathrm{Al}^{3+}$ occurs through the HCP layers of $\mathrm{O}^{2-}$ anions by the mechanism of interstitial migrations. The solid state diffusion of $\mathrm{Al}^{3+}$ ions at $1400^{\circ} \mathrm{C}$ is accompanied by its reaction with $\mathrm{C}_{3} \mathrm{~A}$ to give products $\mathrm{C}_{12} \mathrm{~A}_{7}$ and $\mathrm{CA}$. At temperatures $>1400^{\circ} \mathrm{C}, \mathrm{C}_{12} \mathrm{~A}_{7}$ melts and wets the alumina substrate surface, further enhancing the chemical reaction with that. The diffusion occurring at the interface to give the reaction products can be diagrammatically expressed as in figure 8 with a possible continuous variation in the calcium content. The reactions occuring at the interface, in the case of $\mathrm{C}_{3} \mathrm{~A}$, can be written as

(i) Reaction by solid state diffusion at $1400^{\circ} \mathrm{C}$ :

$$
4 \mathrm{Ca}_{3} \mathrm{Al}_{2} \mathrm{O}_{6}+3 \mathrm{Al}_{2} \mathrm{O}_{3} \rightarrow \mathrm{Ca}_{12} \mathrm{Al}_{14} \mathrm{O}_{33} \text {. }
$$

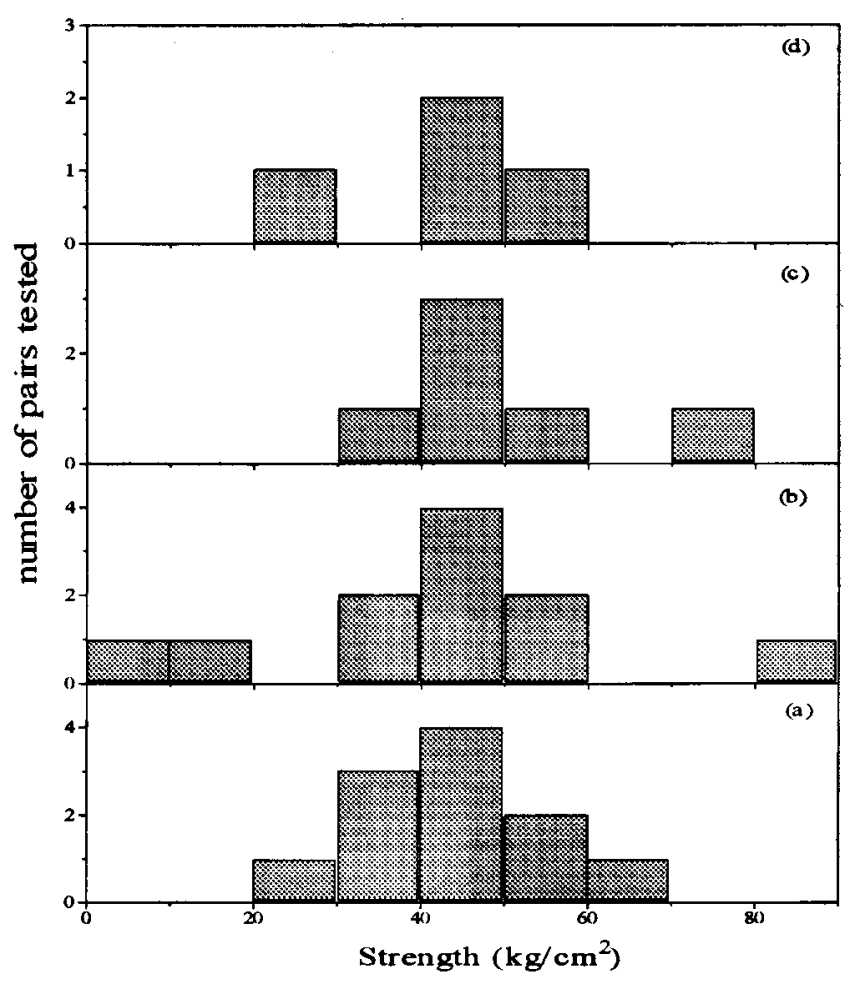

Figure 3. Histogram representing the strength of $\mathrm{C}_{3} \mathrm{~A}$ joined alumina specimens heated at (a) 1400, (b) 1450, (c) 1500 and (d) $1550^{\circ} \mathrm{C}$. (ii) Reaction involving a liquid phase at $>1400^{\circ} \mathrm{C}$ :

$$
\mathrm{Ca}_{12} \mathrm{Al}_{14} \mathrm{O}_{33}(1)+5 \mathrm{Al}_{2} \mathrm{O}_{3}(\mathrm{~s}) \rightarrow 12 \mathrm{CaAl}_{2} \mathrm{O}_{4}(\mathrm{~s}) \text {. }
$$

In the case of $\mathrm{C}_{2} \mathrm{~A}$ cement, $\mathrm{C}_{12} \mathrm{~A}_{7}+\mathrm{C}_{3} \mathrm{~A}$ being the evolving crystalline phases while heating, the reaction (2) can directly take place when applied to the alumina surface and heated to temperatures $>1400^{\circ} \mathrm{C}$. Since $\mathrm{C}_{12} \mathrm{~A}_{7}$ melts by itself at these temperatures, the wetting can be selfinitiated. However, due to difference in the calcium cation concentration in cement (50 mole\%) and the alumina substrate $(0$ mole $\%)$, the reaction of $\mathrm{C}_{12} \mathrm{~A}_{7}$ with the alumina can take place to give an alumina richer compound as well.

The formation of liquid phase is minimal in the case of CA. However, the SEM microstructures and XRD patterns show evidences of partial melting and reaction respectively. Presence of small quantities of $\mathrm{C}_{12} \mathrm{~A}_{7}$ along with the nominal CA composition may be the reason for this. The liquid phase, though in minor quantities, can still provide partial wetting and hence the observed joining for CA composition.

SEM result of the $\mathrm{C}_{3} \mathrm{~A}$ joined alumina essentially shows a molten phase in the joint region. Wetting of the alumina substrates is observed thereby restricting the debonding at the substrate-joint interface. The reactions result in the formation of different phases of calcium aluminates, which wet the alumina specimen surface. This wetting of the alumina substrate by the reaction products result in the filling up of all pores giving rise to strong joints. The different phases in the joint surface, all being calcium aluminates, can have similarity in properties and this composite mixture gives a chemical gradient, which is much better than having abrupt boundary due to a single phase. The temperature range around $1450^{\circ} \mathrm{C}$ is found to be the most optimum for producing good joints. This temperature is

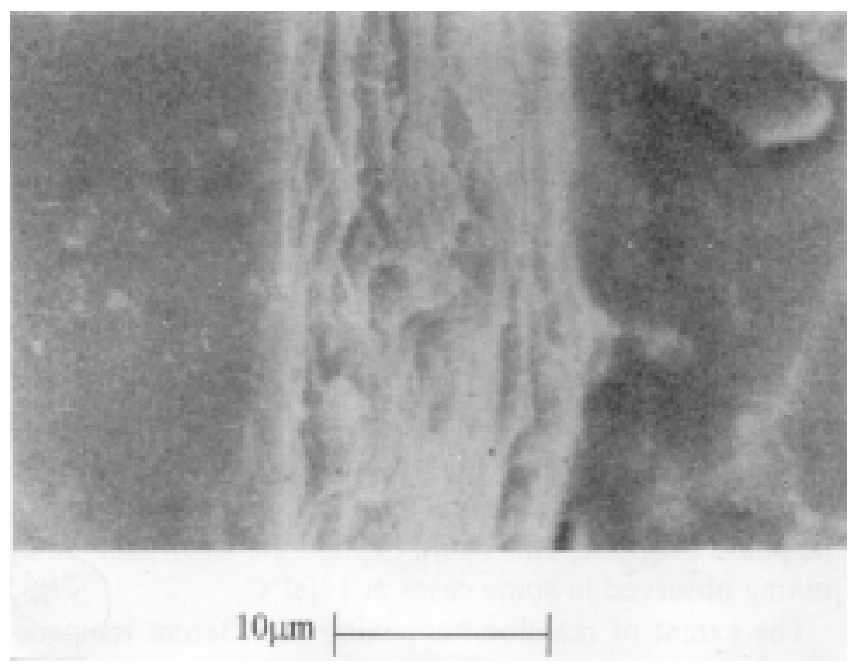

Figure 4. Scanning electron micrograph showing both the joint and base alumina specimens. 
just above the eutectic points of $\mathrm{C}_{3} \mathrm{~A}$ and $\mathrm{C}_{12} \mathrm{~A}_{7}$ and hence the joining is assisted by the wetting of the alumina surface by the liquid phases thus formed.

Even though the eutectic point of $\mathrm{C}_{3} \mathrm{~A}+\mathrm{C}_{12} \mathrm{~A}_{7}$ lies at $1400^{\circ} \mathrm{C}$, there may not be much liquid phases or the melt may be too viscous. Hence, the joining obtained at this temperature may not be the optimum. Higher temperatures of 1500 to $1550^{\circ} \mathrm{C}$ do not seem to have any significant advantage in improving joint strength because, as observed in figure 7 , higher temperature treatment seems to
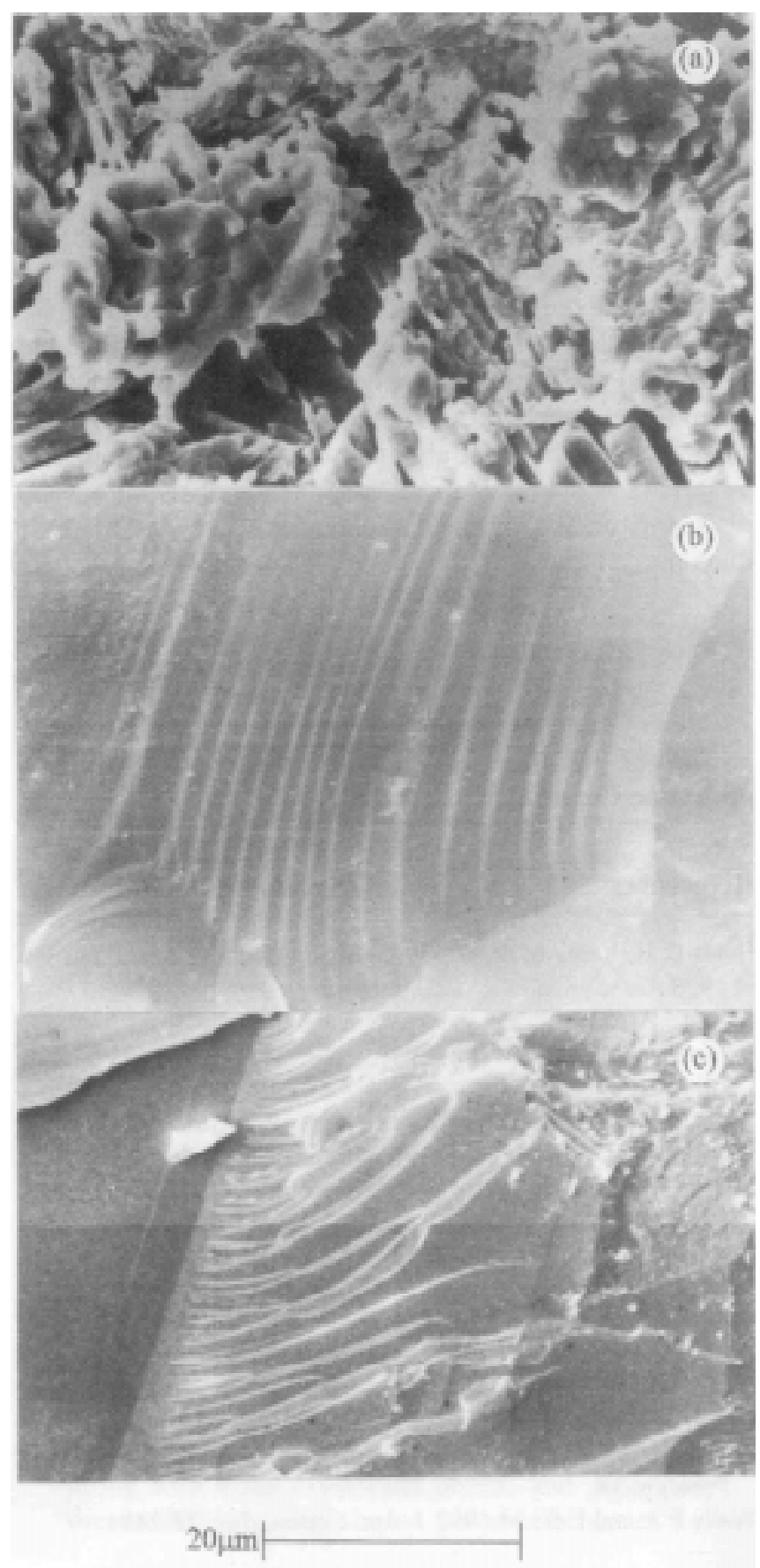

Figure 5. Scanning electron micrographs of the fractured surfaces of the joints (a) $\mathrm{CA}$, (b) $\mathrm{C}_{12} \mathrm{~A}_{7}$ and (c) $\mathrm{C}_{3} \mathrm{~A}$.

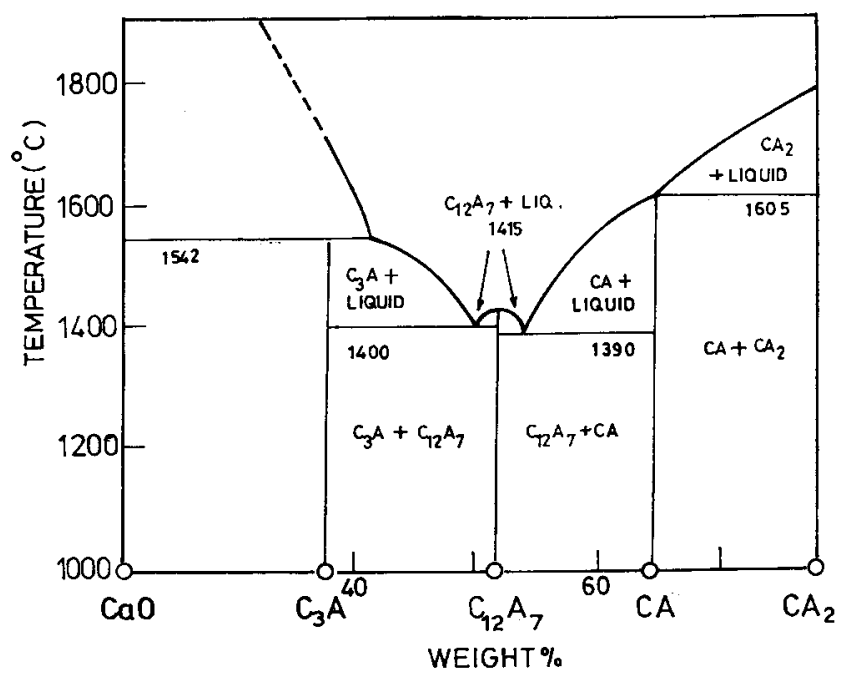

Figure 6. Expanded central region of calcia-alumina phase diagram in the presence of small amounts of $\mathrm{H}_{2} \mathrm{O}$ and $\mathrm{CO}_{2}$ (Taylor 1990).

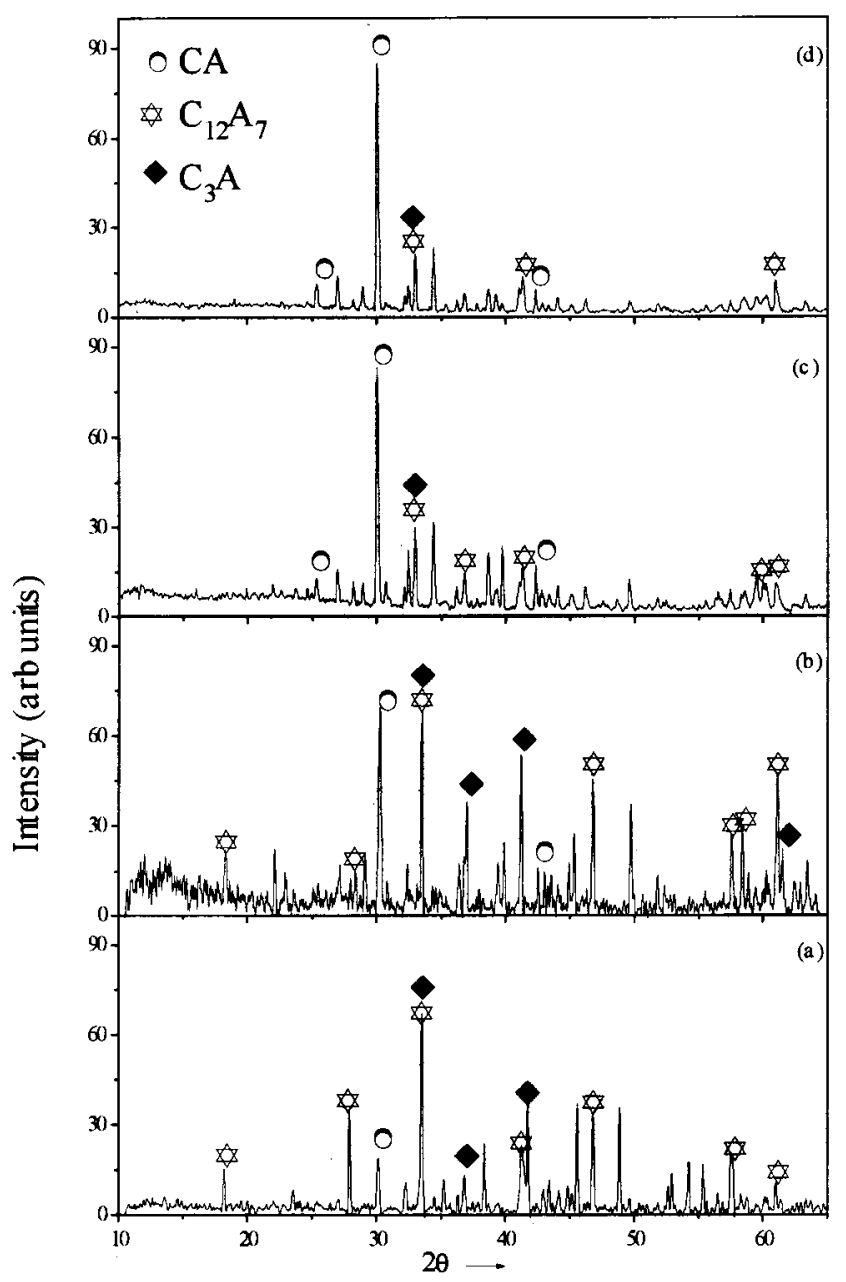

Figure 7. $\mathrm{C}_{3} \mathrm{~A}$ applied alumina joined at different temperatures for the duration of $4 \mathrm{~h}$ (a) 1400, (b) 1450, (c) 1500 and (d) $1550^{\circ} \mathrm{C}$. 


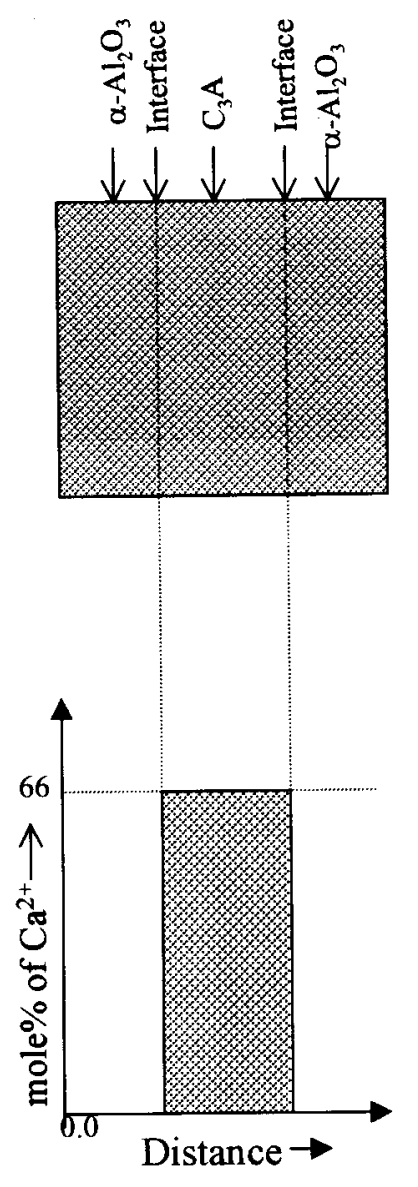

(a)

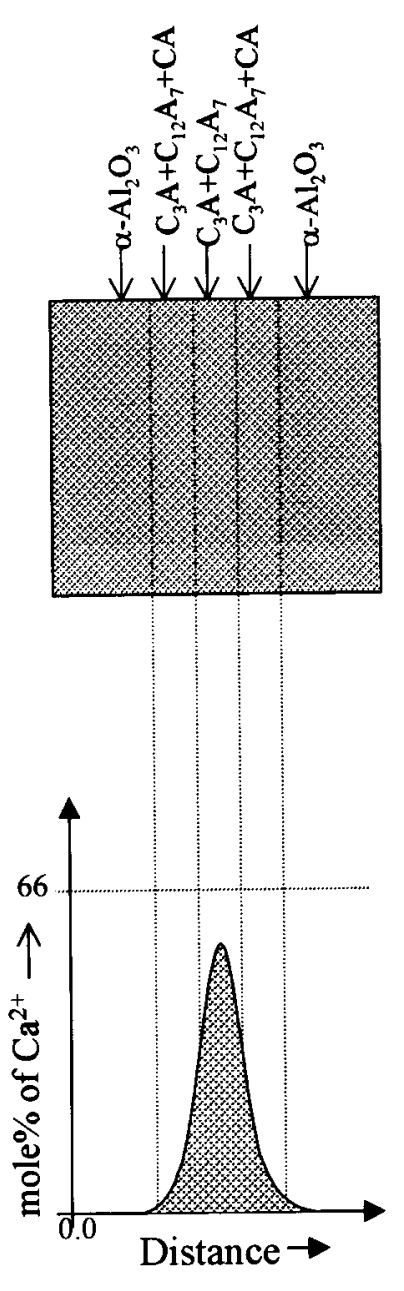

(b)
Figure 8. Schematic expression of calcium concentration at the alumina substrate- $\mathrm{C}_{3} \mathrm{~A}$ interface (a) before and (b) after heat treatment for joining.

produce a predominantly single phase (CA), which can be counter productive by way of enhanced brittleness. Further if the melt becomes less viscous at temperatures $>1400^{\circ} \mathrm{C}$ at the initial state of joining, as it can also happen at shorter time durations of joining, it can prove to be disadvantageous for retaining the physical strength of the joined region.

The relatively better performance of $\mathrm{C}_{3} \mathrm{~A}$ over $\mathrm{C}_{12} \mathrm{~A}_{7}$ and CA refractory cements could depend on the mole percentage of calcium ions present. $\mathrm{C}_{3} \mathrm{~A}$ with cation concentration of $66 \mathrm{~mole} \% \mathrm{Ca}^{2+}$ will have higher reaction potential with alumina as compared to $\mathrm{C}_{12} \mathrm{~A}_{7}$ (46 mole\%) and CA (33 mole\%). The reaction bonding of $\mathrm{C}_{3} \mathrm{~A}$ can then be more effective in producing eutectic liquid phase along with other crystalline phases and generating a gradient composite. The liquid phase is however a transient one, as further reaction with the substrate should yield CA which does not by itself melt up to $1600^{\circ} \mathrm{C}$. Thus, apart from temperature, time duration at the joining temperature also plays an important role in controlling different solidification products and residual liquid present in the joint area; thereby influencing strength of the joints at room temperature.

\section{Conclusions}

$\mathrm{G} \rightarrow \mathrm{C}$ conversion method has been used to prepare finegrained refractory cements of different materials and compositions. Successful cements could be obtained by calcining these powders at 800 to $1200^{\circ} \mathrm{C}$. Out of the various refractory cements tried, the $\mathrm{C}_{3} \mathrm{~A}$ composition is found to be the most advantageous for alumina joint formation at $1450^{\circ} \mathrm{C}$. The study of fractured surface of the resultant alumina joints formed by heating at $1450^{\circ} \mathrm{C}$ for $4 \mathrm{~h}$ indicate the reaction of $\mathrm{C}_{3} \mathrm{~A}$ composition with the alumina substrate. The SEM shows clear melting and solidification. The XRD analysis shows the existence of reaction products of $\mathrm{Al}_{2} \mathrm{O}_{3}$ with the refractory cement. Thus the mechanism of alumina joining obtained here can be termed as the reaction bonding. These observations are discussed on the basis of the binary $\mathrm{CaO}-\mathrm{Al}_{2} \mathrm{O}_{3}$ phase diagram.

\section{Acknowledgement}

All India Council of Technical Education (AICTE) is acknowledged for financial support by way of a research project on Ceramic Joining.

\section{References}

Bates C H, Foley M R, Rossy G A, Sundberg G J and Wu F J 1990 Am. Ceram. Soc. Bull. 69350

Fernie J A 1997 Ceram. Trans. 773

Jayaraman V, Periaswamy G and Kutty T R N 1998 Mater. Chem. \& Phys. 5246

Kutty T R N and Padmini P 1992 Mater. Res. Bull. 27945

Kutty T R N and Padmini P 1995 Mater. Chem. \& Phys. 39200

Kutty T R N, Jayaraman V and Periaswamy G 1996 Mater. Res. Bull. 311159

Loeman R E and Tomsia A P 1988 Ceram. Bull. 67375

Meek T T and Blake R D 1986 J. Mater. Sci. Lett. 5270

Nayak M and Kutty T R N 1996 Mater. Res. Bull. 31227

Padmini P and Kutty T R N 1994 J. Mater. Chem. 41875

Palaith D and Silberglitt R 1989 Am. Ceram. Soc. Bull. 681601

Parker K M and Sharp J H 1982 Trans. Br. Ceram. Soc. 8135

Taylor H F W 1990 Cement chemistry (New York: Academic Press) p. 34

Walls P A and Ueki M 1992 J. Am. Ceram. Soc. 752491 